\title{
Active Site and Electronic Structure Elucidation of Pt Nano- particles Supported on Phase-pure Molybdenum Carbide Nanotubes
}

Lucun Wang, Shibely Saha, Rebecca Fushimi, Dongmei Li, Shuai Tan

March 2017

The INL is a U.S. Department of Energy National Laboratory operated by Battelle Energy Alliance

Idaho National Laboratory 


\title{
Active Site and Electronic Structure Elucidation of Pt Nano-particles Supported on Phase-pure Molybdenum Carbide Nanotubes
}

\author{
Lucun Wang, Shibely Saha, Rebecca Fushimi, Dongmei Li, Shuai Tan
}

March 2017

Idaho National Laboratory Idaho Falls, Idaho 83415

http://www.inl.gov

Prepared for the U.S. Department of Energy Office of Nuclear Energy Under DOE Idaho Operations Office

Contract DE-AC07-05ID14517 


\title{
Active Site and Electronic Structure Elucidation of Pt Nanoparticles Supported on Phase-pure Molybdenum Carbide Nanotubes
}

\author{
Shuai Tan ${ }^{\mathrm{a}, \mathrm{c}}$, Lucun Wang b,c, Shibely Saha a, Rebecca R Fushimi b,c, Dongmei Li a,c,* \\ ${ }^{\text {a }}$ Department of Chemical Engineering, University of Wyoming, Laramie, WY 82071, USA \\ b Biological and Chemical Processing Department, Energy and Environment Science and Technology, Idaho Na- \\ tional Laboratory, Idaho Falls, ID, USA 83415 \\ ${ }^{\mathrm{c}}$ Center for Advanced Energy Studies, Idaho Falls, ID, USA 83401.
}

Supporting Information Placeholder

\begin{abstract}
We recently showed that phase-pure molybdenum carbide nanotubes can be durable supports for Pt nanoparticles in hydrogen evolution reaction (HER). Here we characterize surface properties of the same $\mathrm{Pt} / \beta-\mathrm{Mo}_{2} \mathrm{C}$ catalyst platform using carbon monoxide (CO)-Pt and $\mathrm{CO}-\mathrm{Mo}_{2} \mathrm{C}$ bond strength of different Pt particle sizes in the $<3 \mathrm{~nm}$ range. Results from diffuse reflectance infrared Fourier transform spectroscopy (DRIFTS) and temporal analysis of products (TAP) revealed the existence of different active sites as Pt particle size increases. Correlation between the resultant catalyst activity and deposited Pt particle size was further investigated using water-gas-shift (WGS) as a probe reaction, suggesting that precise control of particle diameter and thickness is needed for optimized catalytic activity.
\end{abstract}

Early work of Levy and Boudart ${ }^{1}$ indicated the platinum (Pt)-like properties of transition metal carbides (TMCs), resulting from their similarity to $\mathrm{Pt}$ in geometric and electronic structures. Recent work has focused on replacing Pt with TMCs in electrochemical devices, such as PEMFC and eletrolyzers. ${ }^{2-5}$, Catalytic properties of TMCs, especially molybdenum carbide $\left(\mathrm{Mo}_{2} \mathrm{C}\right)$ and $\mathrm{Pt} / \mathrm{Mo}_{2} \mathrm{C}$, for low temperature water gas shift (WGS) have also been investigated. ${ }^{6-11}$ Schweitzer et al. reported the superiority of $\mathrm{Pt} / \mathrm{Mo}_{2} \mathrm{C}$ catalyst over the oxide supported catalysts and predicted that the WGS reaction occurred near the $\mathrm{Pt} / \mathrm{Mo}_{2} \mathrm{C}$ interface, followed by computational simulation. ${ }^{11}$ Using both ex situ and in situ x-ray absorption (XAS), Sabins et al found that the synergy between Pt-Mo alloy nanoparticle and $\mathrm{Mo}_{2} \mathrm{C}$ was the cause for the enhanced $\mathrm{Pt} / \mathrm{Mo}_{2} \mathrm{C}$ activity. ${ }^{8,9}$ Despite the comprehensive investigation on the origin of the enhanced catalytic activity of $\mathrm{Pt} / \mathrm{Mo}_{2} \mathrm{C}$ catalysts relative to bare $\mathrm{Mo}_{2} \mathrm{C}$, there still lacks study on how the size of supported noble metal, such as $\mathrm{Pt}$, affects resultant metal/carbide catalyst activity when: 1 ) both the TMC support and deposited metal particles are in the nano-scale regime; 2 ) the carbide support has pristine phase purity.

Chemical properties of supported metals can be attributed to two effects: ligand and strain effect. ${ }^{12,13}$ Ligand effect results from orbital interaction between a deposited metal and its support, inducing electronic charge transfer at the interface, while strain effect results from lattice mismatch. These effects often result in d-band center shift and, consequently, changes in metal-adsorbate bond strength and catalytic reactivity of resultant catalysts. ${ }^{14-16}$ Here we report a unique $\mathrm{Pt} / \mathrm{Mo}_{2} \mathrm{C}$ catalyst platform where phase-pure $\mathrm{Mo}_{2} \mathrm{C}$ nanotube was used as a support, with Pt deposited onto the support in a rotary atomic layer deposition (ALD) reactor. ${ }^{2}$ Such atomic level size control has only been achieved on oxide supports ${ }^{17-19}$ until recently. ${ }^{20}$ In contrast to the mesoporous $\mathrm{Mo}_{2} \mathrm{C}$ structures used in open literature, ${ }^{8}$ which makes imaging studies difficult, the phasepure $\mathrm{Mo}_{2} \mathrm{C}$ nanotube in our recent study provides muchneeded detail of $\mathrm{Pt}$ lattice as $\mathrm{Pt}$ particle size grows from atomic to 2-3 $\mathrm{nm} .{ }^{20}$ Specifically, 15, 50 and 100 ALD cycles were chosen based on pioneering work ${ }^{21}$ with resultant samples referred to as 15,50 and $100 \mathrm{Pt} / \mathrm{Mo}_{2} \mathrm{C}$.

Table.Si summarizes Pt mass loading, Brunauer, Emmett and Teller (BET) surface area and Pt NP sizes. We note that mass loading of $\mathrm{Pt}$ in ${ }_{15} \mathrm{Pt} / \mathrm{Mo}_{2} \mathrm{C}$ sample was too small to be detected using inductively coupled optical emission spectrometry (ICP-OES). Pt particle size measured by hydrogen $\left(\mathrm{H}_{2}\right)$ chemisorption increased from $0.2-0.3 \mathrm{~nm}$ in $15 \mathrm{Pt} / \mathrm{Mo}_{2} \mathrm{C}$ to $\sim 2 \mathrm{~nm}$ in $50 \mathrm{Pt} / \mathrm{Mo}_{2} \mathrm{C}$ sample and to $\sim 2.7 \mathrm{~nm}$ Pt particles size in $100 \mathrm{Pt} / \mathrm{Mo}_{2} \mathrm{C}$, consistent with size measurement using transmission electron microscopy (TEM) images (Fig.S2). It should be noted that no $\mathrm{H}_{2}$ adsorption was observed from bare $\mathrm{Mo}_{2} \mathrm{C}$ samples, confirming that Pt are the only $\mathrm{H}_{2}$ absorption sites. Different from the raft-like Pt particles supported on $\mathrm{Mo}_{2} \mathrm{C}$ reported by Schweitzer et al, ${ }^{11}$ both TEM images and $\mathrm{Pt}$ dispersion suggest that NPs of $5 \mathrm{O} \mathrm{Pt} / \mathrm{Mo}_{2} \mathrm{C}$ have smaller diameter $(2 \mathrm{~nm})$ and are thinner than those in $100 \mathrm{Pt} / \mathrm{Mo}_{2} \mathrm{C}(2.7$ $\mathrm{nm})$. In other words, as the Pt particles grow in diameter with increasing ALD cycles, their thickness also increases. While TEM images qualitatively revealed this trend, the higher dispersion in $50 \mathrm{Pt} / \mathrm{Mo}_{2} \mathrm{C}$ (57\%) than $100 \mathrm{Pt} / \mathrm{Mo}_{2} \mathrm{C}(41 \%)$ measured via $\mathrm{H}_{2}$ chemisorption quantitatively proved this observation. As shown in Fig. $\mathrm{S}_{3}, 5 \mathrm{O} \mathrm{Pt} / \mathrm{Mo}_{2} \mathrm{C}$ samples also have the largest binding energy (BE) shift (o.7o eV) from $\mathrm{Pt}^{\circ}(74.5 \mathrm{eV}$ in ${ }_{4} \mathrm{f}_{5 / 2}$ ) among the 15,50 and $100 \mathrm{Pt} / \mathrm{Mo}_{2} \mathrm{C}$ samples, indicating strongest interaction between $\mathrm{Pt} \mathrm{NPs}$ and the $\mathrm{Mo}_{2} \mathrm{C}$ nanotube 
support. ${ }^{20}$ Mun et al ${ }^{22}$ attributed the core-level shift to electron transfer between Pt atom and its support, often referred to as ligand effect. ${ }^{12}$ We recently demonstrated that strain effect from the metal-support lattice mismatch is also responsible for enhanced electrochemical activity of resultant catalysts (Fig. $\mathrm{S}_{4}$ and $\mathrm{S}_{5}$ ). ${ }^{20}$ We hypothesize that smaller and thinner $\mathrm{Pt}$ particles of $5 \mathrm{O} \mathrm{Pt} / \mathrm{Mo}_{2} \mathrm{C}$ possess more substantial amount of sites affected by the strain-ligand effect than those in 100 $\mathrm{Pt} / \mathrm{Mo}_{2} \mathrm{C}$ NPs. Thicker particles allow Pt sites on top surface to be excluded from the strain-ligand effect.

To experimentally correlate the strain-ligand effect with Ptadsorbate bond strength for different Pt NP sizes, diffuse reflectance infrared Fourier transform spectroscopy (DRIFTS) was utilized to characterize $\mathrm{CO}$ adsorption on $\mathrm{Pt} / \mathrm{Mo}_{2} \mathrm{C} .19,23,24$ Temperature programmed desorption (TPD) was carried out for both bare $\mathrm{Mo}_{2} \mathrm{C}$ and $\mathrm{Pt} / \mathrm{Mo}_{2} \mathrm{C}$ samples. Since all samples are black powders, they were diluted to $1 \%(\mathrm{wt})$ in potassium bromide (non-absorbing matrix) to ensure strong scattered light signals. Fig. S6 provides the peaks for $\mathrm{CO}$ molecules adsorbed on $\mathrm{Mo}_{2} \mathrm{C}$ sites $\left(\mathrm{CO}-\mathrm{Mo}_{2} \mathrm{C}\right)$ as a baseline. For 50 and 100 $\mathrm{Pt} / \mathrm{Mo}_{2} \mathrm{C}$ samples, two additional peaks were observed. A unique peak at $2165 \mathrm{~cm}^{-1}$ was observed with $50 \mathrm{Pt} / \mathrm{Mo}_{2} \mathrm{C}$, which was assigned to $\mathrm{CO}$ molecules adsorbed on cationic Pt atoms $\left(\mathrm{CO}-\mathrm{Pt}^{\delta+}\right){ }^{19} \mathrm{~A}$ wide peak at low intensity $\left(2030-2070 \mathrm{~cm}^{-1}\right)$ for $50 \mathrm{Pt} / \mathrm{Mo}_{2} \mathrm{C}$ was assigned to $\mathrm{CO}$ molecules linearly adsorbed on $\mathrm{Pt}^{\circ}$ sites $\left(\mathrm{CO}-\mathrm{Pt}^{\mathrm{o}}\right.$ ), while two separate peaks (2064 and 2087 $\mathrm{cm}^{-1}$ ) were present for $\mathrm{CO}-\mathrm{Pt}^{\circ}$ bonds on $100 \mathrm{Pt} / \mathrm{Mo}_{2} \mathrm{C}$ surface. The less significant peak at $2087 \mathrm{~cm}^{-1}$ that appeared after $5 \mathrm{~min}$ of He purging at $150^{\circ} \mathrm{C}$ was speculated to be the $\mathrm{CO}$ molecules linearly adsorbed onto weekly coordinated $\mathrm{Pt}^{\mathrm{o}}$ at larger $\mathrm{Pt}$ particles $>3 \mathrm{~nm} .{ }^{25}$
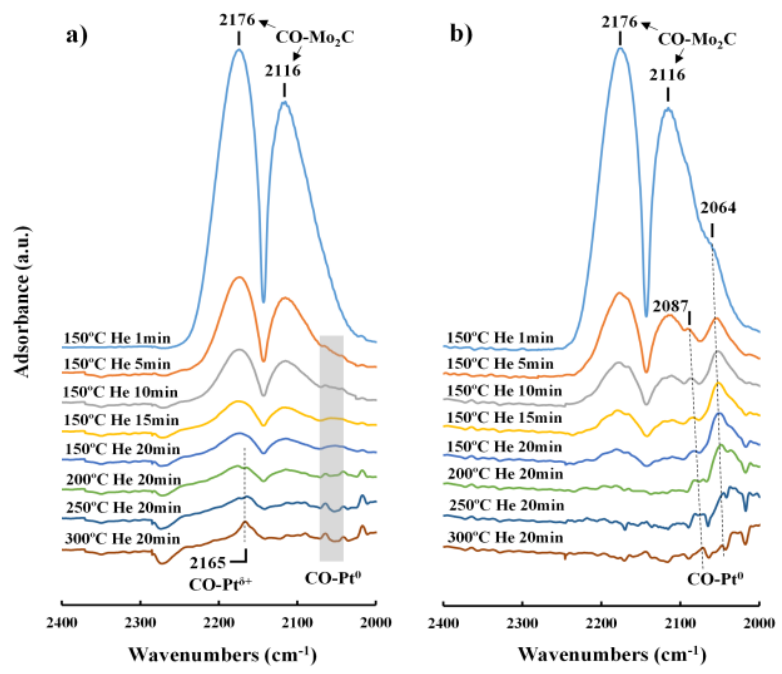

Figure 1. DRIFTS results of CO-TPD under different helium purging time and temperatures on: a) $50 \mathrm{Pt} / \mathrm{Mo}_{2} \mathrm{C}$ and b) 100 $\mathrm{Pt} / \mathrm{Mo}_{2} \mathrm{C}$.

We note that there is a lack of $\mathrm{CO}-\mathrm{Pt}^{\delta+}$ signals from 100 $\mathrm{Pt} / \mathrm{Mo}_{2} \mathrm{C}$, compared to $50 \mathrm{Pt} / \mathrm{Mo}_{2} \mathrm{C}$, indicating that thicker $\mathrm{Pt}$ particles have substantially less $\mathrm{Pt}$ atoms impacted by strainligand effect since $\mathrm{Pt}^{\delta+}$ sites are the results of strong ligandstain effect. In other words, the higher signal intensity from $\mathrm{CO}-\mathrm{Pt}^{\delta+}$ than $\mathrm{CO}-\mathrm{Pt}^{\mathrm{o}}$ in ${ }_{50} \mathrm{Pt} / \mathrm{Mo}_{2} \mathrm{C}$ indicate that $\mathrm{CO}-\mathrm{Pt}^{\delta+}$ sites dominated the electronic nature of Pt NPs, as depicted in Fig.2a (left), which is consistent with the fact that $50 \mathrm{Pt} / \mathrm{Mo}_{2} \mathrm{C}$ possesses the highest $\mathrm{Pt}$ dispersion (57\%) summarized in Table $\mathrm{S}_{1}$ and largest $\mathrm{BE}$ shift $(0.70 \mathrm{eV})$ among all the $\mathrm{Pt} / \mathrm{Mo}_{2} \mathrm{C}$ samples (Fig.S3). In contrast, dominating amount of Pt sites in $100 \mathrm{Pt} / \mathrm{Mo}_{2} \mathrm{C}$ samples were not affected significantly by strainligand effect as the particles grow thicker, except for those along the peripheral interface and in the proximity with $\mathrm{Mo}_{2} \mathrm{C}$ substrate (Fig. 2a, right). Consequently, $\mathrm{CO}-\mathrm{Pt}^{\circ}$ signals were much stronger for $100 \mathrm{Pt} / \mathrm{Mo}_{2} \mathrm{C}$ than for $50 \mathrm{Pt} / \mathrm{Mo}_{2} \mathrm{C}$, consistent with the much lower BE shift from $\mathrm{Pt}^{\circ}(0.22 \mathrm{eV})$ and significantly lower dispersion (41\%).

a)

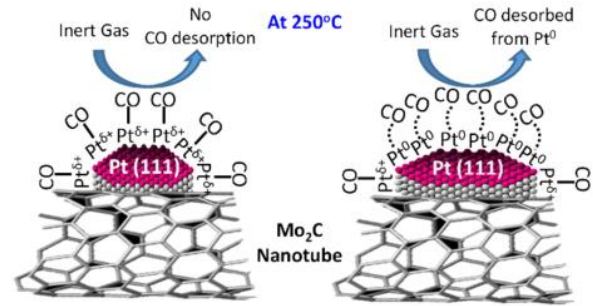

b)

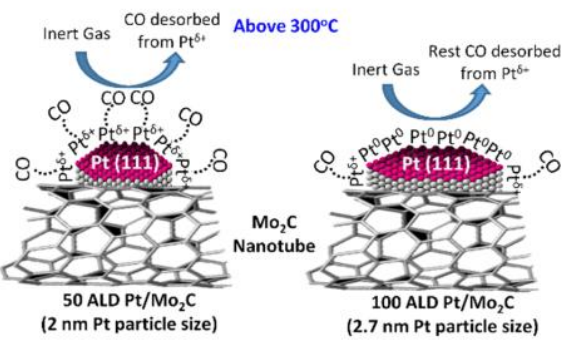

Figure 2. Schematic of $\mathrm{CO}$ desorption process at different temperatures for 50 (left) and $100 \mathrm{Pt} / \mathrm{Mo}_{2} \mathrm{C}$ (right).

$\mathrm{CO}$ bond strength to $\mathrm{Mo}_{2} \mathrm{C}$ sites provides another crucial indicator of surface properties. For $100 \mathrm{Pt} / \mathrm{Mo}_{2} \mathrm{C}$ (Fig.lb), the intensities of $\mathrm{CO}-\mathrm{Mo}_{2} \mathrm{C}$ peaks decreased with longer helium (He) purging time at $150^{\circ} \mathrm{C}$, indicating the removal of CO molecules from $\mathrm{Mo}_{2} \mathrm{C}$ surface. This peak remained constant for over 20 minutes for both 50 and $100 \mathrm{Pt} / \mathrm{Mo}_{2} \mathrm{C}$ till temperature increases to $200^{\circ} \mathrm{C}$. However, these two samples responded differently with temperature increase. For $100 \mathrm{Pt} / \mathrm{Mo}_{2} \mathrm{C}, \mathrm{CO}$ molecules adsorbed on $\mathrm{Mo}_{2} \mathrm{C}$ sites were removed substantially at $200^{\circ} \mathrm{C}$, evidenced by the disappearance of $\mathrm{CO}-\mathrm{Mo}_{2} \mathrm{C}$ peaks (Fig. 1b). The intensity of $\mathrm{CO}-\mathrm{Mo}_{2} \mathrm{C}$ peaks in $50 \mathrm{Pt} / \mathrm{Mo}_{2} \mathrm{C}$ sample only had a slight decrease when temperature increased to 200-250 ${ }^{\circ} \mathrm{C}$ and did not disappear until temperature increased to $300{ }^{\circ} \mathrm{C}$. We postulate that the strong strain-ligand effect in the smaller and thinner $50 \mathrm{Pt} / \mathrm{Mo}_{2} \mathrm{C}$ NPs may have affected the electronic structure $\mathrm{Mo}_{2} \mathrm{C}$ sites, possibly forming Pt-Mo alloy. ${ }^{8}$

Similar trend with temperature was also observed for $\mathrm{CO}$ $\mathrm{Pt}^{\mathrm{o}}$ peaks. For $100 \mathrm{Pt} / \mathrm{Mo}_{2} \mathrm{C}$, intensity of the linear $\mathrm{CO}-\mathrm{Pt}^{\mathrm{o}}$ peaks remained constant at $200^{\circ} \mathrm{C}$, but significantly decreased when temperature increased to $250^{\circ} \mathrm{C}$ and above, indicating desorption of $\mathrm{CO}$ molecules from $\mathrm{Pt}^{\circ}$ sites, as depicted in Fig.2a (right). It was also worth noting that these two peaks red-shifted to lower frequency with He purging time and temperature increase (dashed lines in Fig. 1b). This was attributed to dipole-dipole coupling change between $\mathrm{CO}$ and $\mathrm{Pt}$ atom as $\mathrm{CO}$ coverage decreased.19,26 The signal of $\mathrm{CO}-\mathrm{Pt}^{\circ}$ for 50 $\mathrm{Pt} / \mathrm{Mo}_{2} \mathrm{C}$ is fairly weak, following a similar trend to 100 $\mathrm{Pt} / \mathrm{Mo}_{2} \mathrm{C}$ with He purging time. When temperature increased to $200^{\circ} \mathrm{C}$, the signal further weakened to the noise level of DRIFTS. However, the dominating CO- $\mathrm{Pt}^{\delta+}$ signal from 50 $\mathrm{Pt} / \mathrm{Mo}_{2} \mathrm{C}$ remained at $300^{\circ} \mathrm{C}$ and became sharper (Fig.1a), suggesting that $\mathrm{CO}$ desorption temperature from $\mathrm{Pt}^{\delta+}$ sites is above $300^{\circ} \mathrm{C}$ (Fig.2b, left). 
To correlate the $\mathrm{CO}-\mathrm{Pt}^{\circ}$ and $\mathrm{CO}-\mathrm{Pt}^{\delta+}$ bond strength with catalytic activity, temporal analysis of products (TAP) reactor system $^{27}$ was used to carefully examine the effect of $\mathrm{CO}$ adsorption/desorption on $\mathrm{CO}$ oxidation step $\left(\mathrm{CO} \rightarrow \mathrm{CO}_{2}\right)$ by temperature programmed $\mathrm{CO}$ pulse response experiments. One advantage of transient experiments in vacuum is the higher time resolution that enables observation of subtle processes that could be missed in DRIFTS experiment. Following the removal of surface species during pretreatment process (see ESI for detail), the samples were exposed to $\mathrm{CO}$ pulses at room temperature first. High CO retention, shown in Fig.3, was detected for all samples with the greatest per pulse reaching $90 \%$ for the $50 \mathrm{Pt} / \mathrm{Mo}_{2} \mathrm{C}$ sample. The $\mathrm{CO}$ molecules must be strongly bound to the surface because no gas phase products were detected. This enhanced CO interaction supports the strain-ligand effect hypothesis indicated by the XPS and DRIFTS results (Fig. $\mathrm{S}_{3}$ and Fig.1). $\mathrm{CO}$ also interacts with the pristine $\mathrm{Mo}_{2} \mathrm{C}$ and $100 \mathrm{Pt} / \mathrm{Mo}_{2} \mathrm{C}$ sample at room temperature. However, for these materials $\mathrm{CO}_{2}$ production was observed (Fig.3). Particularly for the bare $\mathrm{Mo}_{2} \mathrm{C}$ material, a $\mathrm{CO}_{2}$ fractional yield near $40 \%$ was detected. The carbon balance shows significant $\mathrm{CO}$ retention on the surface for all materials (Fig. 4a). The pronounced $\mathrm{CO}_{2}$ production at room temperature from $\mathrm{Mo}_{2} \mathrm{C}$ and $100 \mathrm{Pt} / \mathrm{Mo}_{2} \mathrm{C}$ can be attributed to the forward Boudouard reaction $\left(2 \mathrm{CO} \rightarrow \mathrm{C}+\mathrm{CO}_{2}\right)$. Pulse response experiments using $\mathrm{CO}$ isotopes are needed to definitively rule out participation of the surface species. However, the participation of surface species is considered unlikely since sustained $\mathrm{CO}_{2}$ production, as shown in Fig.S7, was observed for all samples as pulses continued with temperature being slowly increased at the same time.

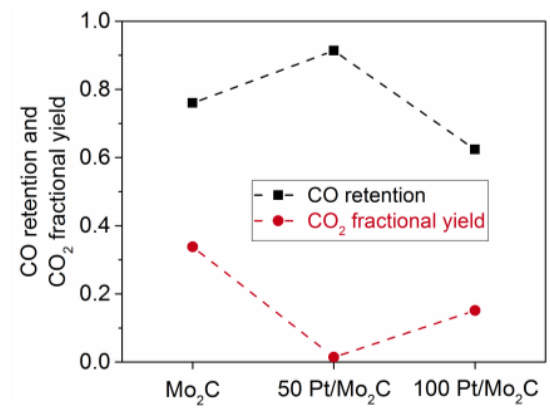

Figure 3. $\mathrm{CO}$ retention and $\mathrm{CO}_{2}$ fractional yield when $\mathrm{CO}$ is pulsed at room temperature in vacuum.

When observing pulse response shape such as those in Fig.S7, the most obvious point of reference is the peak height. Although the $\mathrm{CO}_{2}$ production rapidly drops for the $\mathrm{Mo}_{2} \mathrm{C}$ sample (Fig. $\mathrm{S}_{7} \mathrm{a}$ ) in the initial pulses, indicating adsorption site poisoning through carbon accumulation, it remains sustained throughout the experiment. The carbon mass balance suggests a significant amount of the pulsed $\mathrm{CO}$ is not detected in the gas phase products and remains on the surface. A clearer interpretation of the $\mathrm{CO}$ and $\mathrm{CO}_{2}$ pulse response data is presented in Fig.4, with the $\mathrm{CO}$ retention in each pulse and the $\mathrm{CO}_{2}$ yield being indicated.
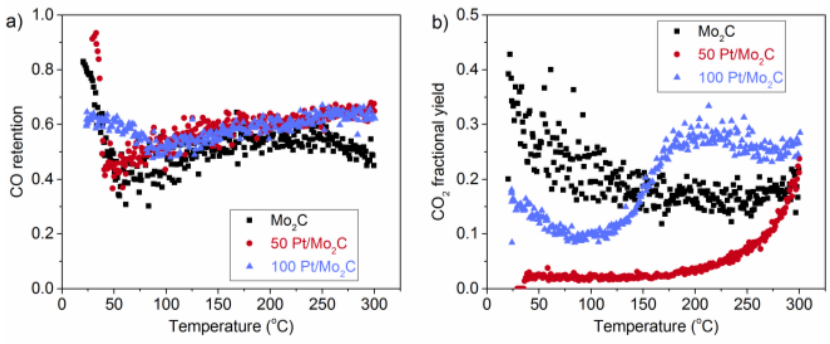

Figure 4. $\mathrm{CO}$ retention (a) and $\mathrm{CO}_{2}$ fractional yield (b) for different samples.

All samples indicate an initial drop in $\mathrm{CO}$ retention when temperature increased from room temperature to $50^{\circ} \mathrm{C}$, which could be attributed to site poisoning by $\mathrm{C}$ accumulation from the forward Boudouard reaction. As the temperature increases, however, there is a turning point (Fig.4a) where $\mathrm{CO}$ retention begins to increase (near $50^{\circ} \mathrm{C}$ for $\mathrm{Mo}_{2} \mathrm{C}$ and 50 $\mathrm{Pt} / \mathrm{Mo}_{2} \mathrm{C}$, near $100{ }^{\circ} \mathrm{C}$ for $100 \mathrm{Pt} / \mathrm{Mo}_{2} \mathrm{C}$ ). The $\mathrm{CO}_{2}$ production for the $\mathrm{Mo}_{2} \mathrm{C}$ sample continuously drops as the temperature is raised and plateaued around $150^{\circ} \mathrm{C}$. The $50 \mathrm{Pt} / \mathrm{Mo}_{2} \mathrm{C}$ sample maintains $\mathrm{CO}$ retention (Fig. 4a) but does not indicate $\mathrm{CO}_{2}$ production until temperatures greater than $150^{\circ} \mathrm{C}$ are reached (Fig.4b). At $200^{\circ} \mathrm{C}$ the $\mathrm{CO}$ retention is still high while $\mathrm{CO}_{2}$ production is low indicating that $\mathrm{CO}$ is strongly bound to the surface in corroboration with the CO-Pt ${ }^{\delta+}$ peak for $50 \mathrm{Pt} / \mathrm{Mo}_{2} \mathrm{C}$ in DRIFTS data (Fig. 1a). The fact that bare $\mathrm{Mo}_{2} \mathrm{C}$ support and the $5 \mathrm{O} \mathrm{Pt} / \mathrm{Mo}_{2} \mathrm{C}$ catalyst does not behave the same for $\mathrm{CO}_{2}$ production suggests that the ALD deposited Pt NPs in $50 \mathrm{Pt} / \mathrm{Mo}_{2} \mathrm{C}$ may have changed the electronic structure of the $\mathrm{Mo}_{2} \mathrm{C}$ surface. The $100 \mathrm{Pt} / \mathrm{Mo}_{2} \mathrm{C}$ sample indicates unique behavior for temperature dependent $\mathrm{CO}_{2}$ production with a low temperature regime $\left(100-275^{\circ} \mathrm{C}\right)$ transitioning to a higher temperature regime $\left(>275^{\circ} \mathrm{C}\right)$ where $\mathrm{CO}_{2}$ yield is pronounced (Fig.S $7 \mathrm{C}$ and Fig.4b). This indicates the presence of distinct routes to $\mathrm{CO}_{2}$ formation through different active sites, consistent with XPS (Fig.S3), HRTEM (Fig.S4) and DRIFTS results (Fig.2).

The particle size effect on catalytic activity was also investigated under WGS conditions using catalysts loading of 400 and $100 \mathrm{mg}$ (Fig. 5 and Fig. S9). Both 50 and $100 \mathrm{Pt} / \mathrm{Mo}_{2} \mathrm{C}$ showed significantly enhanced $\mathrm{CO}$ conversion, compared to bare $\mathrm{Mo}_{2} \mathrm{C}$ nanotubes. $50 \mathrm{Pt} / \mathrm{Mo}_{2} \mathrm{C}$ generally required higher working temperature, which is very pronounced in the temperature range of $200-350^{\circ} \mathrm{C}$ and reflected by a slightly higher apparent activation energy $\left(\mathrm{E}_{\mathrm{a}}\right)(55.8 \mathrm{~kJ} / \mathrm{mol})$ than that of 100 $\mathrm{Pt} / \mathrm{Mo}_{2} \mathrm{C}(53.6 \mathrm{~kJ} / \mathrm{mol})$ (Fig.S8). We attribute this to the fact that ${ }_{50} \mathrm{Pt} / \mathrm{Mo}_{2} \mathrm{C}$ has more substantial amount of Pt atoms affected by strain-ligand effect than $100 \mathrm{Pt} / \mathrm{Mo}_{2} \mathrm{C}$. The stronger bonding of $\mathrm{CO}-\mathrm{Pt}^{\delta+}$ required higher temperature to activate the $\mathrm{Pt}^{\delta+}$ sites, which resulted in lower WGS rate in $50 \mathrm{Pt} / \mathrm{Mo}_{2} \mathrm{C}$ than in $100 \mathrm{Pt} / \mathrm{Mo}_{2} \mathrm{C}$ for low temperature range. However, when temperature increased above $300^{\circ} \mathrm{C}, 50 \mathrm{Pt} / \mathrm{Mo}_{2} \mathrm{C}$ showed $\sim 2.5$ times higher WGS rate $\left(0.82 \mathrm{~mol} \mathrm{CO} / \mathrm{mol}_{\mathrm{Pt}} \cdot \mathrm{s}\right)$ than 100 $\mathrm{Pt} / \mathrm{Mo}_{2} \mathrm{C}\left(0.35 \mathrm{~mol} \mathrm{CO} / \mathrm{mol}_{\mathrm{Pt}} \cdot \mathrm{s}\right)$. For the same reaction conditions, similar WGS rate trend was observed for lower catalyst loading (100 mg, Fig.S9). 

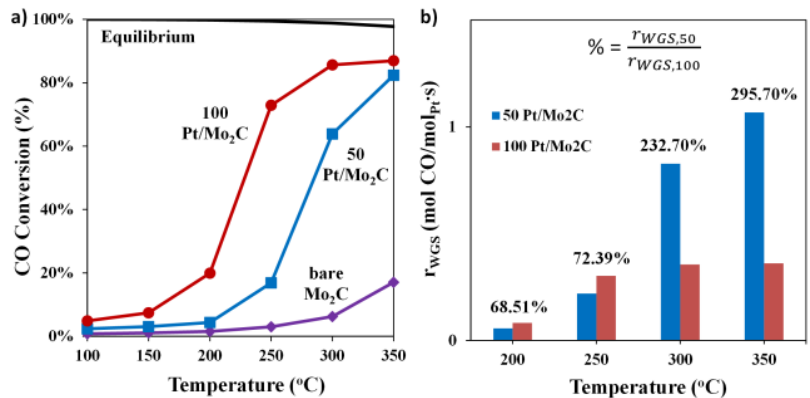

Figure 5. The $\mathrm{CO}$ conversion (a) and WGS rate (mol $\left.\mathrm{CO} / \mathrm{mol}_{\mathrm{Pt}} \cdot \mathrm{s}\right)$ (b) of $\mathrm{Pt} / \mathrm{Mo}_{2} \mathrm{C}$ catalysts for WGS (12.5\% CO$37.5 \% \mathrm{H}_{2} \mathrm{O}-50 \% \mathrm{~N} 2$ feed condition at $\left.15000 \mathrm{~h}^{-1} \mathrm{GHSV}\right)$.

To summarize, we demonstrated that Pt NPs deposited on phase-pure $\mathrm{Mo}_{2} \mathrm{C}$ nanotube can be used as an experimental platform for elucidating active sites and electronic structure of both $\mathrm{Pt}$ and $\mathrm{Mo}_{2} \mathrm{C}$. The Pt particle size change in the range of $<3 \mathrm{~nm}$ not only resulted in core-level shift of the supported $\mathrm{Pt}$, but may also have changed the electronic structure of nearby $\mathrm{Mo}_{2} \mathrm{C}$ sites, suggested by different $\mathrm{CO}-\mathrm{Mo}_{2} \mathrm{C}$ bond strengths between 50 and $100 \mathrm{Pt} / \mathrm{Mo}_{2} \mathrm{C}$ materials. The biggest $\mathrm{BE}$ shift from $\mathrm{Pt}{ }^{\mathrm{o}}$ for $5 \mathrm{O} \mathrm{Pt} / \mathrm{Mo}_{2} \mathrm{C}$ materials was further corroborated by evident $\mathrm{CO}-\mathrm{Pt}^{\delta+}$ signal in DRIFTS and much higher $\mathrm{CO}_{2}$ production temperature in TAP results. WGS rates suggest that there may be an optimal particle perimeter and thickness that balances working temperature and activity. Future study with X-ray absorption fine structure spectroscopy (XAFS) combined with DRIFTS ${ }^{28}$ will facilitate further probing of the interface between Pt NP and TMC support with the reported $\mathrm{Pt} / \mathrm{Mo}_{2} \mathrm{C}$ catalyst platform.

\section{ASSOCIATED CONTENT}

\section{Supporting Information}

The detailed catalyst preparations, characterizations, TAP and WGS reaction measurements are included in the Electronic Supporting Information (ESI). This material is available free of charge via the Internet at http://pubs.acs.org.

\section{AUTHOR INFORMATION}

\section{Corresponding Author}

Department of Chemical Engineering, University of Wyoming, Laramie, WY, 82072. dli1@uwyo.edu.

\section{ACKNOWLEDGMENT}

We are grateful to Professors Joseph Holle, Maohong Fan and Dr. Erwin Sabio for their assistance with BET/chemisorption, DRIFTS and HRTEM/XPS experiments. We thank the Office of Research and Economic Development, School of Energy Research (SER) and NASA EPSCoR at the University of Wyoming for their generous financial support. We acknowledge of support of the U.S. Department of Energy, under DOE Idaho Operations Office Contract DE-ACo7-05ID14517. Accordingly, the U.S. Government retains a nonexclusive, royalty-free license to publish or reproduce the published form of this contribution, or allow others to do so, for U.S. Government purposes.

\section{REFERENCES}

(1) Levy, R. B.; Boudart, M. Science. 1973, 181 (4099), 547-549.
(2) Wan, C.; Regmi, Y. N.; Leonard, B. M. Angew. Chemie Int. Ed. 2014, 53 (25), 6407-6410.

Zhang, K.; Yang, W.; Ma, C.; Wang, Y.; Sun, C.; Chen, Y.; Duchesne, P.; Zhou, J.; Wang, J.; Hu, Y.; Banis, M. N.; Zhang, P.; Li, F.; Li, J.; Chen, L. NPG Asia Mater. 2015, 7 (1), e153. . 2013, 3 (6), 1184-1194.

(5) Hunt, S. T.; Milina, M.; Alba-rubio, A. C.; Hendon, C. H.; Dumesic, J. A.; Román-leshkov, Y. Science (80-. ). 2016, 352 (6288), 974-978.

(11) Schweitzer, N. M.; Schaidle, J. a; Ezekoye, O. K.; Pan, X. Linic, S.; Thompson, L. T. J. Am. Chem. Soc. 2011, 133, 23782381.

(12) Kitchin, J. R.; Nørskov, J. K.; Barteau, M. a.; Chen, J. G. Phys. Rev. Lett. 2004, 93 (15), 4-7.

(13) Strasser, P.; Koh, S.; Anniyev, T.; Greeley, J.; More, K.; Yu, C.; Liu, Z.; Kaya, S.; Nordlund, D.; Ogasawara, H.; Toney, M. F.; Nilsson, A. Nat. Chem. 2010, 2 (6), 454-46o.

(14) Jia, Q.; Caldwell, K.; Strickland, K.; Ziegelbauer, J. M.; Liu, Z.; Yu, Z.; Ramaker, D. E.; Mukerjee, S. ACS Catal. 2015, 5 (111), 176.

(15) Friebel, D.; Viswanathan, V.; Miller, D. J.; Anniyev, T.; Ogasawara, H.; Larsen, A. H.; Ogrady, C. P.; Nørskov, J. K.; Nilsson, A. J. Am. Chem. Soc. 2012, 134 (23), 9664-9671.

Xie, S.C Choi, S. II. Lu, N. Roling, L.T.; Herron, J. a.; Zhang, L.; Park, J.; Wang, J.; Kim, M. J.; Xie, Z.; Mavrikakis, M.; Xia, Y. Nano Lett. 2014, 14 (6), 3570-3576.

Peterson, E. J.; DeLaRiva, A. T.; Lin, S.; Johnson, R. S.; Guo, H.; Miller, J. T.; Hun Kwak, J.; Peden, C. H. F.; Kiefer, B.; Allard, L. F.; Ribeiro, F. H.; Datye, A. K. Nature communications. 2014, p 4885.

(18) Setthapun, W.; Williams, W. D.; Kim, S. M.; Feng, H.; Elam, J. W.; Rabuffetti, F. a.; Poeppelmeier, K. R.; Stair, P. C.; Stach, E. a.; Ribeiro, F. H.; Miller, J. T.; Marshall, C. L. J. Phys. Chem. C 2010, 114 (21), 9758-9771.

(19) Ding, K.; Gulec, A.; Johnson, A. M.; Schweitzer, N. M.; Stucky, G. D.; Marks, L. D.; Stair, P. C. Science (8o-. ). 2015 350 (6257), 1688-169o.

(20) Saha, S.; Martin, B.; Leonard, B.; Li, D. J. Mater. Chem. A Mater. energy Sustain. 2016, 4, 9253-9265.

(21) Hsu, I. J.; Hansgen, D. A.; Mccandless, B. E.; Willis, B. G.; Chen, J. G. J. Phys. Chem. C 2011, 115 (9), 3709-3715.

(22) Mun, B.; Lee, C.; Stamenkovic, V.; Markovic, N.; Ross, P. Phys. Rev. B 2005, 71 (11), 115420.

(23) Green, I. X.; Tang, W.; Neurock, M.; Yates Jr., J. T. Science (80-. ). 2011, 333, 736-740.

(24) Wang, J.; Kispersky, V. F.; Nicholas Delgass, W.; Ribeiro, F. H. J. Catal. 2012, 289, 171-178.

(25) Bazin, P.; Saur, O.; Lavalley, J. C.; Daturi, M.; Blanchard, G. Phys. Chem. Chem. Phys. 2005, 7, 187-194.

(26) Crossley, A.; King, D. A. Surf. Coatings Technol. 1977, 68, 528-538.

(27) Gleavesa, J. T.; Yablonskii, G. S.; Phanawadee, P.; Schuurmanb, Y. Appl. Catal. A Gen. 1997, 160, 55-88. Brieger, C.; Melke, J.; Bosch, N. Van Der; Reinholz, U.; Riesemeier, H.; Guilherme, A.; Krishna, M.; Derr, I.; Schökel, A.; Roth, C. J. Catal. 2016, 339, 57-67. 


\section{For Table of Contents Only}

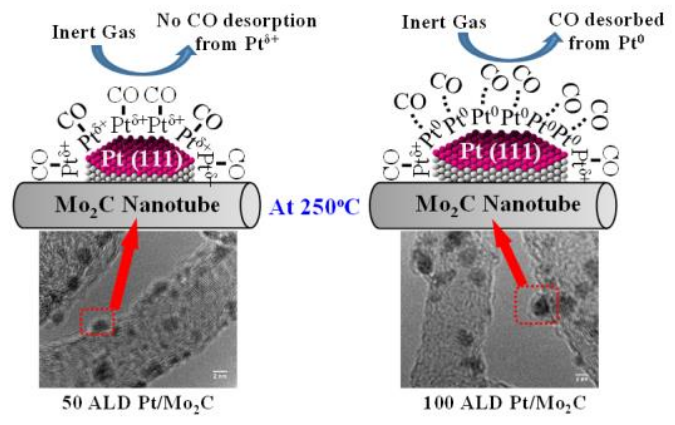

